Fixed Point Theory, 22(2021), No. 1, 105-122

DOI: $10.24193 /$ fpt-ro.2021.1.08

http://www.math.ubbcluj.ro/ nodeacj/sfptcj.html

\title{
A NEW ALGORITHM FOR SOLVING A SYSTEM OF GENERALIZED MIXED EQUILIBRIUM PROBLEMS AND FINDING COMMON FIXED POINTS OF A FINITE FAMILY OF BREGMAN NONEXPANSIVE MAPPINGS IN BANACH SPACES
}

\author{
VAHID DARVISH* AND TRUONG MINH TUYEN** \\ * School of Mathematics and Statistics, \\ Nanjing University of Information Science and Technology, \\ Nanjing 210044, China \\ E-mail: vahid.darvish@mail.com \\ ** Department of Mathematics and Informatics, \\ Thainguyen University of Sciences, \\ Thai Nguyen, Vietnam \\ E-mail: tuyentm@tnus.edu.vn
}

\begin{abstract}
In this paper, we introduce a new general iterative algorithm for finding a common element of the set of common fixed points of a finite family of Bregman nonexpansive mappings and the set of solutions of systems of generalized mixed equilibrium problems.

Key Words and Phrases: Banach space, Bregman mapping, fixed point, System of generalized mixed equilibrium, system of mixed variational inequality.

2020 Mathematics Subject Classification: 47H05, 47J25, 58C30, 47H10.
\end{abstract}

\section{REFERENCES}

[1] Y.I. Alber, Metric and generalized projection operators in Banach spaces: properties and applications, in: A.G. Kartsatos (Ed.), Theory and Applications of Nonlinear Operator of Accretive and Monotone Type, Marcel Dekker, New York, 1996, 15-50.

[2] M. Aslam Noor, W. Oettli, On general nonlinear complementarity problems and quasi equilibria, Matematiche (Catania), 49(1994), 313-331.

[3] H.H. Bauschke, J.M. Borwein, P.L. Combettes, Essential smoothness, essential strict convexity, and Legendre functions in Banach spaces, Commun. Contemp. Math., 3(2001), 615-647.

[4] E. Blum, W. Oettli, From optimization and variational inequalities to equilibrium problems, Math. Student, 63(1994), 123-145.

[5] J.F. Bonnans, A. Shapiro, Perturbation Analysis of Optimization Problems, New York, Springer, 2000.

The first author is supported by the Talented Young Scientist Program of Ministry of Science and Technology of China (Iran-19-001).

The second author was supported by the Science and Technology Fund of Thai Nguyen University of Sciences (TNUS). 
[6] F.E. Browder, Existence and approximation of solutions of nonlinear variational inequalities, Proc. Natl. Acad. Sci. USA, 56(1966), 1080-1086.

[7] R.E. Bruck, S. Reich, Nonexpansive projections and resolvents of accretive operators in Banach spaces, Houston J. Math., 3(1977), 459-470.

[8] D. Butnariu, A.N. Iusem, Totally Convex Functions for Fixed Points Computation and Infinite Dimensional Optimization, Applied Optimization, 40, Kluwer Academic, Dordrecht, 2000.

[9] D. Butnariu, S. Reich, A.J. Zaslavski, Asymptotic behavior of relatively nonexpansive operators in Banach spaces, J. Applied Analysis, 7(2001), 151-174.

[10] D. Butnariu, S. Reich, A.J. Zaslavski, There are many totally convex functions, J. Convex Anal., 13(2006), 623-632.

[11] D. Butnariu, E. Resmerita, Bregman distances, totally convex functions and a method for solving operator equations in Banach spaces, Abstr. Appl. Anal., (2006), art. ID 84919, 1-39.

[12] L.C. Ceng, J.C. Yao, A hybrid iterative scheme for mixed equilibrium problems and fixed point problems, J. Comput. Appl. Math., 214(2008), 186-201.

[13] Y. Censor, A. Lent, An iterative row-action method for interval convex programming, J. Optim. Theory Appl., 34(1981), 321-353.

[14] P.L. Combettes, S.A. Hirstoaga, Equilibrium programming in Hilbert spaces, J. Nonlinear Convex Anal., 6(2005), 117-136.

[15] V. Darvish, A strong convergence theorem for finding a common fixed point of a finite family of Bregman nonexpansive mappings in Banach spaces which solves a generalized mixed equilibrium problem, Boll. Unione Mat. Ital., 9(2016), 421-434.

[16] V. Darvish, Strong convergence theorem for generalized mixed equilibrium problems and Bregman nonexpansive mapping in Banach spaces, Math. Moravica, 20(2016), 69-87.

[17] V. Darvish, Strong convergence theorem for a system of generalized mixed equilibrium problems and Bregman nonexpansive mapping in Banach spaces, Opsearch, 53(2016), 584-603.

[18] S.D. Flam, A.S. Antipin, Equilibrium progamming using proximal-link algolithms, Math. Program., 78(1997), 29-41.

[19] J.B. Hiriart-Urruty, C. Lemaréchal, Grundlehren der mathematischen wissenschaften, in: Convex Analysis and Minimization Algorithms II, 306, Springer-Verlag, 1993.

[20] G. Kassay, S. Reich, S. Sabach, Iterative methods for solving systems of variational inequalities in reflexive Banach spaces, SIAM J. Optim., 21(2011), 1319-1344.

[21] F. Kohsaka, W. Takahashi, Proximal point algorithms with Bregman functions in Banach spaces, J. Nonlinear Convex Anal., 6(2005), 505-523.

[22] W. Kumama, U. Witthayaratb, P. Kumam, S. Suantaie, K. Wattanawitoon, Convergence theorem for equilibrium problem and Bregman strongly nonexpansive mappings in Banach spaces, Optimization, 65(2016), 265-280.

[23] V. Martín-Márquez, S. Reich, S. Sabach, Iterative methods for approximating fixed points of Bregman nonexpansive operators, Discrete Contin. Dyn. Syst. Ser. S., 6(2013), 1043-1063.

[24] J.J. Moreau, Sur la fonction polaire d'une fonction semi-continue supérieurement, C.R. Acad. Sci. Paris, 258(1964), 1128-1130.

[25] J.W. Peng, J.C. Yao, Strong convergence theorems of iterative scheme based on the extragradient method for mixed equilibrium problems and fixed point problems, Math. Comp. Model., 49(2009), 1816-1828.

[26] R.P. Phelps, Convex Functions, Monotone Operators, and Differentiability, Second ed., in: Lecture Notes in Mathematics, vol. 1364, Springer Verlag, Berlin, 1993.

[27] D. Reem, S. Reich, Solutions to inexact resolvent inclusion problems with applications to nonlinear analysis and optimization, Rend. Circ. Mat. Palermo, 67(2018), 337-371.

[28] S. Reich, Constructive techniques for accretive and monotone operators, Applied Nonlinear Analysis, Academic Press, New York, (1979), 335-345.

[29] S. Reich, A weak convergence theorem for the alternating method with Bregman distances, in: Theory and Applications of Nonlinear Operators of Accretive and Monotone Type, Marcel Dekker, New York, 1996, 313-318.

[30] S. Reich, S. Sabach, A strong convergence theorem for a proximal-type algorithm in reflexive Banach spaces, J. Nonlinear Convex Anal., 10(2009), 471-485. 
[31] S. Reich, S. Sabach, Two strong convergence theorems for Bregman strongly nonexpansive operators in reflexive Banach spaces, Nonlinear Anal., 73(2010), 122-135.

[32] S. Reich, S. Sabach, Two strong convergence theorems for a proximal method in reflexive Banach spaces, Numer. Funct. Anal. Optim., 31(2010), 22-44.

[33] S. Reich, S. Sabach, Existence and approximation of fixed points of Bregman firmly nonexpansive mappings in reflexive Banach spaces, in: Fixed-Point Algorithms for Inverse Problems in Science and Engineering, Optimization and Its Applications, 49(2011), 301-316.

[34] S. Reich, S. Sabach, Three strong convergence theorems regarding iterative methods for solving equilibrium problems in reflexive Banach spaces, Contemporary Math., 568(2012), 225-240.

[35] R.T. Rockafellar, Level sets and continuity of conjugate convex functions, Trans. Amer. Math. Soc., 123(1966), 46-63.

[36] S. Suantai, Y.J. Choc, P. Cholamjiak, Halpern's iteration for Bregman strongly nonexpansive mappings in reflexive Banach spaces, Computers and Mathematics with Applications, 64(2012), 489-499.

[37] S. Takahashi, W. Takahashi, Viscosity approximation methods for equilibrium problems and fixed point problems in Hilbert spaces, J. Math. Anal. Appl., 331(2007), 506-515.

[38] W. Takahashi, M. Toyoda, Weak convergence theorems for nonexpansive mappings and monotone mappings, J. Optim. Theory Appl., 118(2003), 417-428.

[39] T.M. Tuyen, Parallel iterative methods for solving systems of generalized mixed equilibrium problems in reflexive Banach spaces, Optimization, 66(2017), 623-639.

[40] H.K. Xu, An iterative approach to quadratic optimization, J. Optim. Theory Appl., 116(2003), 659-678.

[41] C. Zălinescu, Convex Analysis in General Vector Spaces, River Edge (NJ), World Scientific, 2002.

Received: April 14, 2018; Accepted: June 4, 2019. 